\title{
PENERAPAN UNDANG-UNDANG NOMOR 6 TAHUN 2014 TENTANG DESA TERHADAP PERAN PEREMPUAN MELALUI PEMBERDAYAAN MASYARAKAT DESA DI KABUPATEN CIREBON
}

\author{
Leliya \\ Institut Agama Islam Negeri Syekh Nurjati Cirebon \\ Email:leliya12@yahoo.co.id
}

\begin{abstract}
The Role of Village Women in the Industrial Revolution era must play a role in realizing empowerment in the Community, but there are still traditional ideas among Village women who place themselves as second class both in the public and domestic spheres. Even though there are other laws and regulations providing a place for women to play a direct role in the development and empowerment of village communities so that women can be useful. This research uses a qualitative approach. The results of this study are the application of Law No. 6 of 2014 concerning Villages in Cirebon District in enhancing the role of Women through Community Empowerment, basically it has entered in all fields, especially in Cirebon District, as evidenced by the presence of women playing a role in the village. After the Act No. 6 of 2014 concerning Villages towards women's community empowerment, now is very changing for women to participate so as to provide a very broad opportunity for all aspects of life to develop villages.
\end{abstract}

Keywords: Role, Empowerment of Village and Community Women.

\begin{abstract}
Abstrak
Peran Perempuan Desa dalam era Revolusi Industri harus ikut berperan dalam mewujudkan pemberdayaan di Masyarakat, namun masih ada pemikiran tradisional di kalangan perempuan Desa yang menempatkan dirinya sebagai kelas kedua baik di ranah publik maupun ranah domestik. Padahal sudah ada Undang-Undang dan Peraturan lainnya memberikan tempat bagi perempuan untuk berperan langsung dalam pengembangan dan pemberdayaan masyarakat Desa supaya terwujudnya perempuan yang bermanfaat. Penelitian ini menggunakan pendekatan kualitatif. Hasil Penelitian ini adalah Penerapan Undang-Undang Nomor 6 tahun 2014 tentang Desa di Kabupaten Cirebon dalam meningkatkan peran Perempuan melalui Pemberdayaan Masyarakat pada dasarnya sudah masuk di segala bidang khususnya di Kabupaten Cirebon dibuktikan dengan adanya perempuan berperan dalam strukrtur kelembagaan Desa. Setelah adanya Undang-Undang Nomor 6 tahun 2014 tentang Desa terhadap pemberdayaan masyarakat perempuan, saat ini sangat memberikan perubahan kepada perempuan untuk ikut berpartisipasi sehingga memberikan peluang yang sangat luas terhadap semua asfek kehidupan untuk membangun Desa.
\end{abstract}

Kata Kunci: Peran, Pemberdayaan Perempuan Desa dan Masyarakat. 
PENDAHULUAN $\begin{array}{llll}\text { Undang-Undang Nomor } & 6 \text { Tahun } 2014 \\ \text { bertujuan untuk } & \text { mengoptimalkan }\end{array}$ penyelenggaraan Pemerintahan Desa, pelaksanaan pembangunan desa, pembinaan kemasyarakatan desa, dan pemberdayaan masyarakat Desa. Artinya dalam UndangUndang Republik Indonesia Nomor 6 Tahun 2014 mengatur semua aspek pemerintahan desa yang berkaitan dengan pemerintahan desa, pelaksaan pembangunan desa, pembinaan kemasyarakatan desa dan pemberdayaan masyarakat desa. UndangUndang Republik Indonesia Nomor 6 Tahun 2014 merupakan penguatan serta pembaharuan dari undang-undang sebelumnya, bukan berarti undang-undang sebelum Undang-Undang Republik Indonesia Nomor 6 Tahun 2014 tidak berjalan maksimal tetapi lebih diperkuat lagi dengan adanya Undang-Undang Republik Indonesia Nomor 6 Tahun 2014. Desa memiliki hak asal usul dan hak tradisional dalam mengatur dan mengurus kepentingan masyarakat setempat dan berperan dalam mewujudkan cita-cita kemerdekaan berdasarkan Undang-Undang Dasar Negara Republik Indonesia Tahun 1945.

Saat ini, Desa dianggap telah berkembang dalam berbagai bentuk, sehingga perlu dilindungi dan diberdayakan agar menjadi kuat, maju, mandiri, dan demokratis. Tujuannya adalah agar Desa dapat menciptakan landasan yang kuat dalam melaksanakan pemerintahan dan pembangunan menuju masyarakat yang adil, makmur, dan sejahtera. Untuk itulah kemudian terbit Undang-Undang Republik Indonesia Nomor 6 Tahun 2014 tentang desa (Ramli, 2014: 137).

Konsep pembangunan kemampuan peranan perempuan yang dipergunakan berkembang menjadi pemberdayaan perempuan yang berarti meningkatkan kualitas dan peran perempuan pada semua aspek kehidupan baik secara langsung atau tidak langsung melalui penciptaan situasisituasi yang kondusif sebagai motivator dan akslerasi proses pembangunan. Sehingga
Karls (1995) memandang bahwa pemberdayaan kaum perempuan sebagai suatu proses kesadaran dan pembentukan kapasitas (capacity building) terhadap partisipasi yang lebih besar, kekuasaan dan pengawasan dalam pembuatan keputusan dan tindakan transformasi agar menghasilkan persamaan derajat yang lebih besar antara perempuan dan kaum laki-laki (Iriansyah, 2017).

Diakui selama ini ada anggapan bahwa kualitas perempuan dalam pembangunan masih sangat rendah, yang menyebabkan peran kaum perempuan tertinggal dalam segala hal. Maka untuk mengatasinya diperlukan upaya dan strategi mengintegrasikan gender ke dalam arus pembangunan dengan cara menempatkan perempuan sebagai subjek pembangunan dan menghilangkan faktor kendala yang dihadapi perempuan dalam pembangunan dengan melakukan kegiatan analisis dan evaluasi (1) sejauhmana perempuan terlibat dalam program-program pembangunan (2) sejauhmana kualitas tenaga kerja perempuan (3) hambatan-hambatan apa saja yang dihadapi perempuan dalam kegiatan pembangunan (4) upaya-upaya apa saja yang diperlukan untuk meningkatkan kualitas dan peran perempuan (5) faktor apa sajakah yang dominan berpengaruh terhadap hubungan gender dan (6) bagaimana pemecahan masalah yang dihadapi perempuan. Maka dengan kerangka ini tentunya akan dapat dihasilkan suatu identifikasi sejauhmana peranan perempuan dalam pembangunan dewasa ini.

Kondisi ini dapat dipahami begitu besar andil perempuan dalam pembangunan nasional yang diprediksi akan terus meningkat dari tahun ke tahun. Meskipun Women In Development Approach (WID) yang diperkenalkan oleh United States Agency for International Development (USAID) bahwa perempuan merupakan sumber daya yang belum dimanfaatkan secara optimal untuk memberikan sumbangan ekonomi dalam pembangunan. Ini berarti bahwa perempuan dan 
pembangunan telah menjadi sorotan dunia internasional termasuk lembaga swadaya masyarakat (LSM) dalam kajian yang lebih komprehensif. Hubeis (1985) mengatakan, analisis alternatif peran perempuan dalam mendorong pembangunan dapat dilihat dari tiga aspek yakni (1) peran tradisi atau peran domestic yang berkaitan dengan pekerjaan rumah tangga. Perempuan yang berhasil mengelola rumah tangga dengan baik akan menjadi inspirasi dan motivator bagi pelaku pembangunan, (2) peran transisi yang berkaitan dengan garapan lahan pertanian atau bekerja di usaha keluarga dan (3) peran kontemporer. Perempuan memiliki peran di luar rumah tangga atau disebut wanita karier. Peran-peran ini menunjukkan bahwa perempuan baik langsung maupun tidak langsung mempunyai kontribusi yang besar terhadap pembangunan bangsa (Iriansyah, 2017).

Pemerintah telah menempatkan kaum perempuan sebagai partner yang manis bagi pembangunan. Isu gerakan dan pemberdayaan perempuan yang berkembang berkisar dalam suatu pemikiran bahwa perempuan sebagai sumber daya pembangunan, dengan kata lain politik gender telah memakai pendekatan Women In Development dimana perempuan terintegrasi sepenuhnya dalam derap pembangunan nasional. Konsep ini memberikan porsi kepada kaum perempuan untuk lebih eksis meningkatkan peran sertanya dalam pembangunan menuju bangsa yang sejahtera dan penuh kedamaian.

Untuk itu maka penulis merasa perlu untuk mengkaji lebih dalam lagi mengenai, yaitu pertama, bagaimana penerapan Undang-Undang Nomor 6 Tahun 2014 tentang Desa terhadap marginalisasi peran perempuan dalam pembangunan melalui pemberdayaan masyarakat desa di Kabupaten Cirebon? Dan kedua, a dakah perubahan dalam masyarakat desa terhadap peran perempuan melalui pemberdayaan masyarakat atas penerapan Undang-Undang Nomor 6 Tahun 2014 tentang Desa?

\section{LITERATURE REVIEW}

Setelah penulis melakukan penelusuran untuk mengetahui berbagai hasil kajian dan penelitian terdahulu maka ditemukan berbagai judul hasil penelitian serupa yang telah dilakukan berkaitan dengan Penerapan Undang-Undang Nomor 6 Tahun 2014 Tentang Desa terhadap Peran Perempuan Melalui Pemberdayaan Masyarakat Desa di Kabupaten Cirebon, antara lain pertama, Roosganda Elizabeth, Institut Pertanian Bogor (2007) Pemberdayaan Wanita Mendukung Strategi Gender Mainstreaming dalam Kebijakan Pembangunan Pertanian di Pedesaan. Penelitian ini bertujuan mengemukakan berbagai pemikiran (teoritis) tentang peran dan peluang wanita tani, serta memposisikan kembali strategi pengarusutamaan gender (gender mainstreaming) dalam strategi kebijakan pembangunan pertanian di pedesaan. Peran ganda wanita tani membuktikan sangat penting dan strategisnya pola nafkah ganda, sebagai upaya meningkatkan pendapatan. Potensi wanita tani, sebagai istri dan ibu rumah tangga, merupakan faktor penting penentu keberhasilan strategi pengarusutamaan gender tersebut. Pemberdayaan perlu dilakukan melalui teknologi tepat guna dan inovatif, perlindungan terhadap tenaga kerja wanita, meningkatkan efektifitas penyuluhan dan pelatihan, perbaikan regulasi, fasilitas, dan tingkat upah, pelatihan dan pembinaan keterampilan industry rumahtangga.

Kedua, Sri Marwanti dan Ismi Dwi Astuti, Universitas Sebelas Maret (2012) Model Pemberdayaan Perempuan Miskin melalui Pengembangan Kewirausahaan Keluaraga menuju Ekonomi Kreatif di Kabupaten Karanganyar. Penelitian ini bertujuan untuk menganalisis potensi, peluang, hambatan, kebijakan, dan merumuskan model pemberdayaan perempuan miskin dalam mengembangkan kewirausahaan keluarga menuju ekonomi kreatif. Hasil dari penelitian ini adalah Perempuan miskin di daerah pedesaaan perlu diberdayakan melalui pengembangan 
kewirausahaan keluarga menuju ekonomi kreatif. Model yang diusulkan adalah propoor capacity improvement model (PCIM), komponen utama pemberdayaan perempuan miskin adalah: (1) adanya dukungan seluruh stakeholders untuk melalukan programprogram penanggulangan kemiskinan yang responsive gender, (2) Adanya Achievement Motivation Training untuk menumbuhkan kesadaran (keberdayaan) akan pentingnya mengembangkan kewirausahaan keluarga menuju ekonomi kreatif, (3) Pemantapan jejaring antar sesama perempuan miskin pelaku usaha serta pengusaha lokal sebagai media learning by doing, (4) Pembentukan kelompok-kelompok usaha bersama atas dasar kesamaan jenis usaha, (5) Pengembangan kreativitas melalui capacity building agar produk yang dihasilkan menarik, (6) Perluasan sistem bapak angkat dengan melibatkan sebanyak mungkin usahawan lokal sehingga dapat memperkuat modal usaha dan pasar bagi perempuan miskin pelaku usaha.

Ketiga, Wildan Saugi dan Sumarno, Universitas Negeri Yogyakarta (2015) Pemberdayaan Perempuan melalui Pelatihan Pengolahan Bahan Pangan Lokal. Penelitian ini bertujuan untuk mengetahui pelatihan pengolahan bahan pangan lokal yang dapat memberdayakan warga perempuan dusun Pagerjirak, Kejobong, Purbalingga. Hasil dari penelitian ini adalah sebagai berikut: (1) Perencanaan partisipatoris terdiri dari identifikasi kebutuhan dusun dan penyiapan tim pengelola program dusun. (2) Pelaksanaan proses pemberdayaan melalui pelatihan dmulai dengan menyiapkan tim pengelola dan membentuk kelompok usaha,

(3) Indikator Keberhasilan pelatihan diantaranya adalah bertambahnya pengetahuan dan keterampilan warga (4) Keberlanjutan program pemberdayaan perempuan ditunjukkan dengan telah adanya pengembangan produk atau variasi produk dan terbentuknya kemandirian tim.

Penelitian yang dilakukan oleh peneliti berbeda dengan penelitian terdahulu yaitu dalam hal Penerapan Undang-Undang
Nomor 6 Tahun 2014 tentang Desa dalam kaitannya dengan Peran perempuan dan pemberdayaan masyarakat desa.

\section{METODE PENELITIAN \\ Pendekatan Penelitian}

Pendekatan dalam penelitian ini adalah pendekatan kualitatif berupa mengkaji mendeskripsikan, menganalisis data-data dari subyek penelitian di lapangan dengan dasar penelitian studi kasus di Kabupaten Cirebon. Menurut Soemardjono (1989: 6), metodologi adalah suatu saran pokok pengembangan ilmu pengetahuan dan teknologi, oleh karena suatu penelitian bertujuan untuk mengungkap kebenaran secara sistematis, metodologis, dan konsisten dengan mengadakan analisa dan konstruksi Pengertian metode penelitian yang dimaksudkan di sini adalah dalam arti yang umum diterima, yaitu "studi logis dan sistematis tentang prinsip-prinsip yang mengarahkan penelitian ilmiah".

Dalam usaha mencari kebenaran, salah satunya adalah melalui kegiatan ilmiah seperti penelitian di mana dalam penelitian tersebut akan mencari data atau bahan-bahan yang dapat digunakan untuk penulisan ilmiah. Penelitian pada hakekatnya merupakan kegiatan pengumpulan data, pengolahan data, analisa data, dan kontruksi data yang semuanya dilaksanakan secara sistematis dan konsisten. Data adalah gejala yang dicari untuk diteliti, gejala yang diamati oleh peneliti dan hasil pencatatan terhadap gejala yang diamati oleh peneliti.

Pada penelitian ini metode penelitian yang digunakan adalah metode kualitatif. Sehingga fokus penelitian kualitatif diidentifikasikan sebagai berikut.

1. Pengemban ilmu-ilmu sosial.

2. Proses kerjanya berlangusng ringkas, sempit, dan reduksionistik. Reduksi berarti melakukan pembedahan atas sesuatu menjadi bagian-bagian yang bagian itu dapat diuji secara kualitatif.

3. Ketat dalam objektivitas.

4. Basis pengetahuan kausalistis, yaitu menguji hubungan antar fenomena dan 
menentukan kausalitas dari variabelvariabel.

5. Menguji atau mengubah teori. Penelitian melakukan kontrol atas variabel penelitian, menerapkan kontrol yang ketat atas dasar teori, kerangka berpikir, instrumen, teknik analisis, penarikan kesimpulan, penyusunan rekomendasi, dan lain-lain.

6. Melakukan generalisasi.

\section{Fokus Penelitian}

Fokus penelitian yang dibahas dalam penelitian ini adalah Penerapan UndangUndang Nomor 6 tahun 2014 tentang Desa di Kabupaten Cirebon terhadap Peran Perempuan melalui Pemberdayaan Masyarakat Desa studi kasus di Kabupaten Cirebon untuk menghindari terlalu meluasnya masalah yang dibahas maka fokus masalah penelitian dibatasihanya sampai pada:

1. Penerapan Undang-Undang Nomor 6 tahun 2014 tentang Desa di Kabupaten Cirebon terhadap Peran Perempuan melalui Pemberdayaan Masyarakat Desa

2. Perubahan-perubahan dalam Penerapan Undang-Undang Nomor 6 tahun 2014 tentang Desa terhadap Peran Perempuan

\section{Data dan Sumber Data Penelitian}

Sumber data dalam penelitian adalah subjek dari mana data tersebut di peroleh. Dalam penelitian ini terdapat dua sumber data, yaitu sumber data primer dan sumber data sekunder:

1. Data Primer/ Empirik

Menurut Nasution, sumber ini diperoleh penulis dengan terjun langsung ke objek penelitian serta informasiinformasi yang didapat di lokasi penelitian (Nasution, 2003: 143). Penelitian lapangan adalah penelitian dengan cara terjun langsung ke lapangan untuk memperoleh data yang diperlukan dengan jalan wawancara, yaitu pengumpulan data dengan melaksanakan tanya jawab langsung dengan responden yaitu kepala BPMPD Kabupaten
Cirebon, Kepala Kesbanglinmas Kabupaten Cirebon, Kepala Desa, Kepala DPPKBP3A Kabupaten Cirebon, Kepala Biro Pusat Statistik Kabupaten Cirebon

2. Data Sekunder/ Teoritik

Menurut Sumardjono (1989: 20), sumber ini diperoleh dari buku atau pustaka serta literatur lainnya yang berhubungan dengan pokok permasalahan Penerapan UndangUndang Nomor 6 tahun 2014 tentang Desa terhadap Peran Perempuan melalui Pmberdayaan Desa di Kabupaten Cirebon. Penelitian kepustakaan adalah penelitian dengan cara membaca dan mempelajari data-data tertulis yang berupa kitab perundang-undangan, bukubuku, majalah-majalah, makalahmakalah, kliping, dan surat kabar-surat kabar yang berkaitan dengan permasalahan yang akan diteliti (Sumardjono, 1989: 20).

\section{Teknik Pengumpulan Data}

Metode pengumpulan data adalah salah satu proses yang harus dilalui dalam sebuah penelitian, dengan metode ini maka penulis diharapkan akan memperoleh data yang diperlukan. Metode tersebut dilakukan dengan cara:

Dalam pengumpulan data, penulis menggunakan cara sebagai berikut.

1. Wawancara

Wawancara merupakan suatu proses interaksi dan komunikasi semacam percakapan yang bertujuan untuk memperoleh informasi. Dalam penelitian ini wawancara dilakukan langsung dengan kepala instansi pemerintahan terkait, Kepala Desa.

2. Dokumentasi

Dokumentasi yaitu data-data yang diperoleh dari dokumen-dokumen yang ada di Kabupaten, Kecamatan, Desa.

3. Kepustakaan

Yaitu teknik pengumpulan data untuk mencari konsep-konsep yang ada 
relevansinya dengan topik pembahasan yang akan dteliti yakni internet, brosur, buku-buku, dan dokumen lainnya yang ada di kabupaten, kecamatan, desa.

\section{Teknik Penentuan Sampel}

Menurut Nasution, penentuan sampel dilakukan dengan teknik non random sampling, yaitu tidak memberikan kesempatan yang sama kepada setiap individu untuk menjadi anggota sampel (Nasution, 2003). Bentuk metode non random sampling yang akan dipakai adalah "Purposive Sampling". Dalam purposive sampling ini "peneliti menggunakan pertimbangannya sendiri dengan bekal pengetahuan yang cukup tentang populasi untuk memilih anggota-anggota sampel". Ukuran yang digunakan dalam penentuan sampel adalah klasifikasi jumlah skore variabel lemah suatu desa berdasarkan buku petunjuk penentuan desa yang dikategorikan perdesaaan. Desa-desa tersebut adalah Desa Grogol dengan jumlah skore variabel lemahnya tergolong rendah, Desa Pegagan Lor dengan jumlah skore variabel lemahnya tergolong sedang, dan Desa Keraton dengan jumlah skore variabel lemahnya tergolong tinggi.

Adapun cara menentukan populasi dan sampel adalah sebagai berikut.

1. Populasi adalah keseluruhan objek yang akan diteliti yaitu Penerapan UndangUndang Nomor 6 tahun 2014 tentang Desa terhadap Peran perempuan melalui pembeerdaayaan Masyarakat Desa di Kabupaten Cirebon. Populasi dalam penelitian ini menyangkut tiga Kecamatan dan tiga Desa.

2. Sampel adalah bagian dari kumpulan obyek penelitian yang dipelajari dan diamati. Sampel juga merupakan bagian dari populasi yang akan diteliti dan yang dianggap dapat menggambarkan populasi. Menurut Arikunto, "untuk sekedar ancerancer maka apabila populasinya kurang dari 100, lebih baik diambil semua sehingga penelitiannya merupakan penelitian populasi, selanjutnya jika jumlah subjeknya lebih besar dapat diambil antara $10-15 \%$ atau $20-25 \%$ atau lebih". Adapun sampel dalam penelitian ini menggunakan random sampling, yaitu $10 \%$ sehingga sampel yang diteliti sebanyak dua Kecamatan dan Tiga Desa (Arikunto, 1993: 107).

Responden yang diharapkan dapat memberikan data yang dibutuhkan adalah sebagai berikut.

a. Kepala DPPKBP3A Kabupaten Cirebon

b. Kepala BPMPD Kabupaten Cirebon.

c. Kepala Badan Kesbanglinmas Kabupaten Cirebon.

d. Kantor Statistik Kabupaten Cirebon

e. Kepala Desa di Kabupaten Cirebon, yaitu:

1) Kepala Desa Pegagan lor Kecamatan Kapetakan

2) Kepala Desa Keraton Kecamatan Suranenggala

3) Kepala Desa Grogol Kecamatan Gunung Jati

f. Kelompok Masyarakat.

\section{Teknik Analisis Data}

Bahan-bahan yang diperoleh dari hasil penelitian tersebut, kemudian dikumpulkan dan diseleksi untuk diambil data khusus yang berkaitan dengan permasalahan yang akan dibahas, untuk mendapatkan gambaran umum tentang Penerapan Undang-Undang Nomor 6 tahun 2014 tentang Desa terhadap Peran perempuan melalui pemberdaayaan Masyarakat Desa di Kabupaten Cirebon. Data primer dari hasil wawancara yang dikumpulkan secara benar dan tepat. Setelah itu dihubungkan dengan data sekunder kemudian dianalisis. Sifat analisisnya adalah kualitatif, maksudnya disusun secara sistematis, logis, dan yuridis. Sedangkan penelitian ini bersifat deskriptif yaitu penelitian yang memaparkan dan bertujuan memberikan gambaran serta penjelasan dari variabel yang diteliti untuk mendapatkan gambaran umum Penerapan Undang-Undang Nomor 6 tahun 2014 tentang Desa terhadap Peran perempuan melalui pemberdaayaan Masyarakat Desa di Kabupaten Cirebon. 
Teknik analisa data yang digunakan dalam penelitian ini adalah teknik analisa kualitatif dengan mengumpulkan data-data yang diperoleh kemudian dideskripsikan sehingga dapat memberikan gambaran umum tentang Penerapan Undang-Undang Nomor 6 tahun 2014 tentang Desa terhadap Peran perempuan melalui pemberdaayaan Masyarakat Desa di Kabupaten Cirebon.

Penelitian ini menggunakan pendekatan yuridis kualitatif, menginvestigasi dan memahami fenomena seperti apa yang terjadi, mengapa terjadi dan bagaimana terjadinya sekaligus memahami situasi sosial, peristiwa, peran, interaksi dan kelompok. Hal ini dikarenakan pada penelitian ini peneliti menggunakan berbagai sumber data, teori, metode, dan investigator agar informasi yang disajikan konsisten. Pengumpulan data dalam penelitian kualitatif, kualitas riset sangat tergantung pada kualitas dan kelengkapan data yang dihasilkan. Pertanyaan yang selalu diperhatikan dalam pengumpulan data adalah apa, siapa, dimana, kapan, bagaimana. Dalam penelitian ini digunakan teknik pengumpulan data yaitu wawancara, dan analisis dokumen kepustakaan. Dalam penelitian ini wawancara memegang peranan yang sangat penting, karena metode wawancara yang digunakan peneliti untuk mengumpulkan data dan memperoleh informasi.

Dalam penelitian ini metode wawancara yang digunakan yaitu wawancara terbuka dan wawancara terstruktur. Informan dalam pengumpulan informasi pada penelitian ini yang menjadi informan adalah masyarakat desa, tim pelaksana kegiatan, unit pelaksana kegiatan dan pemerintah. Dalam melakukan analisis data peneliti perlu menangkap, mencatat, menginterpretasikan dan menyajikan informasi. Terdapat enam langkah analisis data yang berhubungan dengan reduksi data dan interpretasi. Berkaitan dengan reduksi data, langkahlangkah analisis meliputi, pengorganisasian data, pembuatan kategori dan tema, dan coding data. Interpretasi data dilakukan melalui penjelasan alternatif, dan menulis laporan. Pada penelitian ini tahap-tahap analisis data dilakukan dengan metode trianggulasi data, kemudian mengorganisir data, data reduction menentukan kategori, konsep, tema, pola dan terakhir melakukan interpretasi.

\section{KONSEP DASAR}

\section{Pengertian Peran Perempuan}

Perkembangan dalam berbagai segmen terus berkembang kita harus menambah wawasan supaya bisa menjadi pribadi yang berilmu, berpendidikan, cakap dan tanggap terkait problematika kehidupan sosial. Seperti halnya problematika peran dan perkembangan perempuan seiring berkembangnya zaman. Berbicara terkait peran dalam teori sosial Parson, peran didefenisikan sebagai harapan-harapan yang diorganisasi terkait dengan konteks interaksi tertentu yang membentuk orientasi motivasional individu terhadap yang lain. Melalui pola-pola kultural, cetak biru, atau contoh perilaku ini orang belajar siapa mereka di depan orang lain dan bagaimana mereka harus bertindak terhadap orang lain (Scott, 2011: 228).

Peran penting dari pemahaman sosiologi, karena mendemonstrasikan bagaimana aktivitas individu dipengaruhi secara sosial dan mengikuti pola-pola tertentu. Para sosiolog telah menggunakan peran sebagai unit untuk menyusun kerangka intitusi sosial. Sebagai contoh, sekolah sebagai sebuah institusi sosial bisa dianalisis sebagai kumpulan peran murid dan pengajar yang sama dengan semua sekolah lain (Abercrombie, Hill, \& Turner, 2010: 480).

Harapan yang disematkan dalam perempuan untuk lebih berperan dalam masyarakat tentu dinilai seharusnya ikut berperan dalam problematika masyarakat baik ditatanan pemerintahan maupun lembaga masyarakat lainnya. Namun dalam pelaskanaanya masih saja ada yang beranggapan bahwa perempuan hanya boleh berperan di lingkungan keluarga saja dan tidak diperbolehkan untuk ikut serta dalam 
peroblematika di luar lingkungan keluarga. Analisis peran perempuan dapat dilakukan dari perspektif posisi mereka dalam berurusan dengan pekerjaan produktif tidak langsung (domestik) dan pekerjaan produktif langsung (publik), yaitu sebagai berikut (Hubeis, 2011: 145):

1. Peran Tradisi menempatkan perempuan dalam fungsi reproduksi (mengurus rumahtangga, melahirkan dan mengasuh anak, serta mengayomi suami). Hidupnya $100 \%$ untuk keluarga. Pembagian kerja sangat jelas, yaitu perempuan di rumah dan lelaki di luar rumah.

2. Peran transisi mempolakan peran tradisi lebih utama dari peran yang lain. Pembagian tugas mengikuti aspirasi gender, tetapi eksistensi mempertahankan keharmonisan dan urusan rumah tangga tetap tanggungjawab perempuan

3. Dwiperan memposisikan perempuan dalam kehidupan dua dunia, yaitu menempatkan peran domestik dan publik dalam posisi sama penting. Dukungan moral suami pemicu ketegaran atau sebaliknya keengganan suami akan memicu keresahan atau bahkan menimbulkan konflik terbuka atau terpendam

4. Peran egalitarian menyita waktu dan perhatian perempuan untuk kegiatan di luar. Dukungan moral dan tingkat kepedulian lelaki sangat hakiki untuk menghindari konflik kepentingan pemilahan dan pendistribusian peranan. Jika tidak, yang terjadi adalah masingmasing akan saling berargumentasi untuk mencari pembenaran atau menumbuhkan ketidaknyamanan suasana kehidupan berkeluarga.

5. Peran kontemporer adalah dampak pilihan perempuan untuk mandiri dalam kesendirian. Jumlahnya belum banyak. Akan tetapi benturan demi benturan dari dominasi lelaki atas perempuan yang belum terlalu peduli pada kepentingan perempuan mungkin akan meningkatkan populasinya

\section{Pengertian Desa}

Dalam Kamus Umum Bahasa Indonesia disebutkan desa adalah (1) wilayah yang dihuni oleh sejumlah keluarga yang mempunyai sistem pemerintahan sendiri (dikepalai oleh Kepala Desa), (2) sekelompok rumah diluar kota yang merupakan kesatuan kampong, dusun, (3) udik atau dusun (dalam arti daerah pedalaman atau lawan dari kota), (4) tempat, tanah, daerah (Poerwadarminta, 2007: 286).

Sedangkan dalam Undang-Undang Nomor 6 tahun 2014 tentang Desa yang ditindak lanjuti dalam PP Nomor 43 Tahun 2014 pasal 1 Ayat (1) "Desa adalah Kesatuan masyarakat hukum yang memiliki batas wilayah yang berwenang untuk mengatur dan mengurus urusan Pemerintahan, kepentingan masyarakat setempat berdasarkan Perakarsa masyarakat, hak asal usul, dan/atau hak tradisional yang diakui dan di hormati dalam sistem Pemerintahan Negara Republik Indonesia. Pasal 1 Ayat (2) Pemerintahan Desa adalah penyelenggaraan urusan pemerintahan dan kepentingan masyarakat setempat dalam sistem pemerintahan Negara Kesatuan Republik Indonesia (Sugianto, 2017: 2).

Menurut

Soetardjo

Kartohadikoesoemo, desa adalah suatu kesatuan hukum dimana bermukim suatu masyarakat yang berkuasa dan masyarakat tersebut mengadakan pemerintah sendiri. Sedangkan definisi desa menurut Talizihudu Ndraha dalam bukunya Dimensi-Dimensi Pemerintahan Desa, adalah kesatuan organisasi pemerintahan yang terendah, mempunyai batas wilayah tertentu, langsung dibawah kecamatan, dan merupakan kesatuan masyarakat hukum yang berhak menyelenggarakan rumah tangganya.

Berdasarkan definisi desa di atas, maka dapat disimpulkan bahwa desa juga dapat dikatakan sebagai suatu hasil perpaduan antara kegiatan sekelompok manusia dengan lingkungannya. Hasil dari 
perpaduan itu ialah suatu wujud atau kenampakan di muka bumi yang ditimbulkan oleh unsur-unsur fisiografi, social, ekonomi, politik dan cultural yang saling berinteraksi antar unsur tersebut dan juga dalam hubungannya dengan daerah-daerah lain (Bintarto, 1983: 11).

\section{Pengertian Pemberdayaan Masyrakat}

Pemberdayaan berasal dari bahasa Inggris "empowerment" yang biasa diartikan sebagai pemberkuasaan. Secara konseptual emperworment berasal dari kata power (kekuasaan atau keberdayaan) (Suharto, 2005: 57). Dalam arti pemberian atau peningkatan "kekuasaan" (power) kepada masyarakat yang lemah atau tidak beruntung (Huraerah, 2008: 82). Rappaport (dalam Fahrudin, 2011: 16) mengartikan empowerment sebagai suatu cara dimana rakyat, organisasi dan komunitas diarahkan agar dapat berkuasa atas kehidupannya.

Menurut Suhendra Pemberdayaan adalah suatu kegiatan yang berkesinambungan, dinamis, secara sinergis mendorong keterlibatan semua potensi masyarakat yang ada secara partisipatif. Dengan cara ini akan memungkinkan terbentuknya masyarakat madani yang majemuk, penuh kesinambungan kewajiban dan hak, saling menghormati tanpa ada yang asing dalam komunitasnya (Suhendra \& Kadmasasmita, 2006: 74-75).

Sedangkan pemberdayaan menurut Eddy Papilaya merupakan upaya untuk membangun kemampuan masyarakat, dengan mendorong, memptivasi, membangkitkan kesadaran akan potensi yang dimiliki dan berupaya untuk mengembangkan potensi itu menjadi tindakan nyata (Zubaedi, 2007: 42).

Pemberdayaan masyarakat menurut Ginandjar Kartasasmitha merupakan upaya untuk meningkatkan harkat dan martabat lapisan masyarakat kita yang dalam kondisi sekarang tidak mampu untuk melepaskan diri dari perangkat kemiskinan dan keterbelakangan. Dengan kata lain memberdayakan adalah memampukan dan memandirikan masyarakat (Kartasasmita, 1996: 18).

Berdasarkan definisi pemberdayaan di atas, maka dapat disimpulkan bahwa pemeberdayaan adalah serangkaiaan kegiatan untuk memperkuan kukasaan atau keberdayaan kelompok rentan dan lemah dalam masyarakat, termasuk individuindividu yang mengalami masalah kemiskinan, sehingga mereka memiliki keberdayaan dalam memenuhui kebutuhan hidupnya baik secara fisik, ekonomi, maupun sosial seperti: kepercayaan diri, maupun menyampaikan aspirasi, mempunyai mata pencahariaan, berpartisipasi dalam kegiatan sosial dan mendiri dalam melaksanakan tugas-tugas kehidupanya.

\section{PEMBAHASAN DAN DISKUSI}

Penerapan Undang-Undang Nomor 6 Tahun 2014 tentang Desa di Kabupaten Cirebon dalam meningkatkan peran perempuan melalui pemberdayaan masyarakat Desa

Seiring dengan perkembangan yang terjadi di Masyarakat, Undang-Undang Nomor 6 tahun 2014 memberikan nilai kesepadanan antara warga masyarakat di suatu Desa untuk turut dalam pemberdayaan Masyarakat demi mewujudkan Masyarakat yang tentram. Tanpa membedakan jenis kelamin di suatu Desa tersebut, hal ini dilakukan supaya semua masyarakat ikut berperan langsung dalam hal pengembangan Desa sehingga ketika semua elemen masyarakat ikut serta maka ketentraman di Desa tersebut akan muncul dan sangat sedikit untuk memunculnya konflik antara masyarkat lainnya. Dalam pelaksananannya untuk meningkatkan pemberdayaan Masyarakat berdasarkan ketentuan Undang-Undang Nomor 6 Tahun 2014 Perempuan harus terlibat demi menjunjung harkat dan martabat Perempuan. Biasanya di Kota-Kota Besar Peran Perempuan dalam ranah Domestik maupun Publik sudah berjalan sehingga perempuan terlibat dalam berbagai hal. 
Berdasarkan ketentuan UndangUndang Nomor 6 Tahun 2014 seharusnya di Seluruh Indonesia khususnya di Pemerintahan tingkat Desa bahwasannya Perempuan harus terlibat dalam berbagai aspek pelaksanaan Pemerintahan Desa. Sehingga Undang-Undang Nomor 6 Tahun 2014 itu berjalan. Seperti halnya yang dilakukan peneliti dibeberapa Desa yang berada di Kabupaten Cirebon. Terkait peran perempuan melalui pemberdayaan Masyarakat Desa.

1. Desa Pegagan Lor

Salah satu Desa yang Berada di Kecamatan Kabupaten Cirebon yaitu Desa Pegagan Lor luas Wilayahnya yaitu 41,10 Ha. Jumlah penduduknya dijumlahkan bahwa jumlah penduduk Desa Pegagan Lor untuk Jumlah LakiLaki yaitu 4662 Orang dan Perempuan 4922 Orang Jumlah total penduduk Desa Pegagan Lor yaitu 9584 Orang untuk jumlah Kepala Keluarga sebanyak 3091 KK dan kepadatan Penduduk yaitu 16,11 per KM. Tingkatan pendidikan di Desa Pegagan Lor dimulai dari TK sampai S-2 Sederajat dengan Jumlah keseluruhan yaitu 9.584 Orang.

Pemberdayaan Masyarakat Desa yang terjadi di Desa Pegagan Lor Kabupaten Cirebon berdasarkan penelitian yang dilakukan peneliti bahwa dalam pelaksanaan pemerintahan Desa dalam hal ini perempuan turut ikut serta dalam pemerintahan bahkan Kepala Desa nya Perempuan.

Desa Pegagan Lor menempatkan perempuan turut ikut serta dalam kegiatan masyarakat baik masuk ke dalam jajaran pemerintahan Desa ataupun ikut berpartisipasi dalam berbagai kegiatan yang diadakan Desa tersebut. Hal lain yang perlu diberikan apresiasi bagi penduduk Desa yang Perempuan di Desa Pegang Lor bahwa ada beberapa perempuan menjadi Anggota Badan Permusyawaratan Desa.

Secara keseluruhan maka dapat disimpulkan peran perempuan dalam pemberdayaan masyarakat di Desa Pegagan Lor jika ditinjau dari UndangUndang Nomor 6 tahun 2014 memberikan kesempatan penuh kepada perempuan untuk turut ikut serta menjadi bagian baik di Jajaran Kepengurusan Perangkat Desa, LPMD, BPD dan Lembaga lainnya. Perempuan mempunyai hak untuk berpartisipasi demi memberdayakan masyarakat khususnya perempuan.

2. Desa Keraton

Desa Keraton Kecamatan Suraneneggala Kabupaten Cirebon. Desa Keraton jumlah penduduk Laki-Laki yaitu 2316 Jiwa dan Jumlah penduduk perempuan yaitu 2441 jiwa jumlah keseluruhan penduduk Desa Keraton yaitu 4754 Jiwa. Tingkatan pendidikan yang berada di Desa Keraton Kecamatan Suranenggala Kabupaten Cirebon terdiri dari TK - S2. Dengan adanya Undangundang Nomor 6 tahun 2014 terdapat perubahan sangat signifikan terhadap peran perempuan hal ini nampak pada kepengurusan Lembaga Pemberdayaan Masyarakat (LPM).

Pemberdayan Masyarakat di Desa Keraton khususnya perempuan secara garis besar bahwa pemerintahan Desa memberikan tempat kepada permpuan untuk turut ikut serta dalam berbagai kegiatan mapun dalam kepengurusan lembaga yang berada di bawah naungan Desa. Selain di kepengurusan LPM, Perempuan di Desa Keraton Juga turut ikut serta dalam kepengurusan Karang Taruna.I

Berdasarkan data di atas maka, peran perempuan dalam perkembangan masyarakat desa khususnya di Desa Keraton Kecamatan Suranenggala Kabupaten Cirebon sudah sangat baik dan dalam hal ini pemerintahan Desa memberikan peluang kepada perempuan untuk ikut serta berperan langsung dalam membangun Desa sehingga ketentuan yang tertera dalam Undang-Undang Nomor 6 tahun 2014 tentang Desa, dalam 
hal ini perempuan sudah sangat berperan khususnya dalam pelaksanaan pemberdayaan.

3. Desa Grogol

a. Sejarah Desa Grogol

Secara Administratif Desa Grogol adalah salah satu dari 15 Desa di Wilayah Kecamatan Gunung Jati bagian Kabupaten Cirebon, yang mempunyai luas wilayah $\pm 173 \mathrm{Ha}$ yang berada diketinggian laut $2 \mathrm{mdl}$. Desa Grogol berbatasan dengan beberapa desa yaitu :

1) Sebelah Barat berbatasan dengan Desa Babadan

2) Sebelah Timur berbatasan dengan Desa Kalisapu/LautJawa

3) Sebelah Selatan berbatasan dengan Desa Wanakaya

4) Sebelah Utara berbatasan dengan Sungai Bondet.

b. Kependudukan

Penduduk Desa Grogol berdasarkan data terakhir hasil Sensus Penduduk Tahun 2017 tercatat sebanyak 5084 jiwa. Untuk lebih jelasnya perkembagan penduduk dapat dilihat dala tabel dibawah ini. Pertumbuhan Jumlah Penduduk Tahun 2016 - 2017

\begin{tabular}{|c|c|c|c|c|}
\hline \multirow[t]{2}{*}{ No } & \multirow[t]{2}{*}{ Tahun } & \multicolumn{2}{|c|}{ Jumlah } & \multirow{2}{*}{$\begin{array}{c}\text { Laju } \\
\text { pertumbuhan }\end{array}$} \\
\hline & & Jiwa & KK & \\
\hline 1 & 2016 & 4994 & $\begin{array}{c}123 \\
6\end{array}$ & \\
\hline 2 & 2017 & 5084 & $\begin{array}{c}129 \\
4\end{array}$ & 0,5 \\
\hline
\end{tabular}

c. Aparatur Pemerintah Desa

Jumlah Aparat Pemerintah Desa/Pamong Desa Grogol Tahun 2018 seluruhnya sebanyak 11 (sebelas) orang, terdiri dari 1(satu) orang Kepala Desa/Kuwu dan 10 (sepuluh) orang Perangkat Desa. Pamong Desa terdiri dari 1 (satu) orang Jurutulis, 2 (dua) Tenaga Sekretariat, 4 (empat) orang Pelaksana Teknis Lapangan, Juragan, Raksa
Bumi dan Lebe. Serta 4 (empat) orang Bekel atau Kepala Dusun

Perubahan dalam masyarakat desa terhadap peran perempuan melalui pemberdayaan masyarakat atas penerapan Undang-Undang Nomor 6 Tahun 2014 Tentang Desa

Berdasarkan wawancara yang dilakukan peneliti dengan Nining Wasrini, S.Sos.M.Si Selaku Kabid DPPKBP3A yaitu bidang DPPKBP3A bahwa Pemberdayaan Perempuan di Kabupaten Cirebon sudah berkembang dengan adanya peraturan Undang-Undang Nomor 6 tahun 2014 tentang Desa sangat memberikan dampak signifikan bagi perkembangan perempuan baik di ranah Publik maupun Domestik. Nining melaporkan bahwa ada program untuk pemberdayaan perempuan membuat program yaitu :

1. Pembinaan Kelompok Perempuan Indonesia Maju Mandiri (PRIMA)

2. Kegiatan Bimbingan Manajemen Usaha Bagi Perempuan Dalam Mengelola Usaha (PEKKA)

3. Kegiatan Pembinaan Organisasi Perempuan

4. Sosialisasi Dan Advokasi Kebijakan Penghapusan Buta Aksara Perempuan (PBAP)

5. Pemberdayaan Perempuan Melalui Pengimbangan Industri Rumahan

Selain itu, mengenai peran dan perkembangan perempuan Desa di kabupaten Cirebon, seperti yang dijelaskan oleh Bapak Permana, S.SOS. Kasi DPMD Aparatur Desa dan BPD (Badan Permusyawaratan Desa). berdasarkan data statistik bahwa untuk wilayah Kabupaten Cirebon Desanya berjumlah 412 Desa, 12 Kelurahan dan 40 Kecamatan. Sampai saat ini dalam mewujudkan peran dan pemberdayaan perempuan Desa ada 3 program besar yaitu sebagai berikut:

1. Ekonomi dan Pembangunan

2. Pemberdayaan Sosial dan Budaya

3. Pemerintah Desa 
Pelaksanaan dalam menjalankan roda pemerintahan Desa sampai saat ini diberikan ruang kepada khalayak masyarakat yang mau berperan secara langsung khususnya bagi perempuan karena keterwakilan perempuan di sekitar pemerintahan Desa secara terang benderang dijelaskan pada :

1. PERDA Nomor 2 tahun 2015 tentang PEMDES dan BPD Jo. Perda Nomor 1 tahun 2017 tentang PEMDES dan BPD.

2. PERBUP Nomor 118/2015 (telah dicabut) pada PERBUP tersebut "Manajemen Keterwakilan Perempuan". PERBUP tersebut diganti dengan PERBUP Nomor 64/2018 tentang BPD.

3. PERMENDAGRI Nomor 110/2016 tentang BPD

Pada produk Hukum tersebut sangat memberikan ruang bagi perempuan supaya ikut serta dalam pelaksanaan kegiatan Desa ataupun menjadi perangkat Desa sebagaimana dijelaskan dalam peraturan tersbut di atas, Produk Hukum di Atas terdapat keterwakilan Perempuan dalam pengurus BPD terdapat Dua kriteria yaitu :

1. Keterwakilan Wilayah

2. Keterwakilan Perempuan

Jumlah keterwakilan Perempuan dalam kepengurusan BPD dilihat dari :

1. Wakil 5 orang ketika keadaan penduduk berjumlah 0-2500 Penduduk

2. Wakil 7 orang ketika keadaan penduduk berjumlah 2501-5000 Penduduk

3. Wakil 9 orang ketika keadaan penduduk berjumlah 5001 penduduk.

Berdasarkan pemaparan di atas maka dapat disimpulkan bahwa lahirnya UndangUndang Nomor 6 tahun 2014 tentang Desa Memberikan Dampak Signifikan terhadap Perubahan Masyarakat Desa terhadap peran perempuan, memang dahulu Perempuan tertutup akan tetapi setelah adanya UndangUndang Nomor 6 tahun 2014 tentang Desa baru memberikan peluang yang sangat luas bagi Perempuan terhadap semua aspek Kehidupan untuk membangun Desa.

\section{KESIMPULAN}

Berdasarkan hasil penelitian yang dilakukan, dapat diambil 2 (dua) macam kseimpulan, yaitu pertama, berdasarkan penelitian yang didapat dari data serta fakta yang didapat maka dapat disimpulkan bahwa Penerapan Undang-Undang Nomor 6 tahun 2014 tentang Desa di Kabupaten Cirebon dalam meningkatkan peran Perempuan melalui Pemberdayaan Masyarakat pada dasarnya sudah masuk di segala bidang khususnya di Kabupaten Cirebon dibuktikan dengan adanya perempuan berperan dalam strukrtur kelembagaan Desa dari mulai Kepala Desa, Juru tulis, pengurus LPMD, Karang Taruna, Rt., Rw., dan Hansip.

Dan kedua, Setelah adanya UndangUndang Nomor 6 tahun 2014 tentang Desa terhadap pemberdayaan masyarakat perempuan, saat ini sangat memberikan perubahan kepada perempuan untuk ikut berpartisipasi sehingga memberikan peluang yang sangat luas terhadap semua aspek kehidupan untuk membangun Desa. 
DAFTAR PUSTAKA

Abercrombie, N., Hill, S., \& Turner, B. S. (2010).

Kamus

Sosiologi. Yogyakarta: Pustaka Pelajar.

Arikunto, S. (1993). Prosedur Penelitian Suatu Pendekatan Praktik. Jakarta: Rineka Cipta.

Bintarto, R. (1983). Interaksi Desa-Kota dan Permasalahannya. Jakarta: Ghalia Indonesia.

Fahrudin, A. (2011). Pemberdayaan, Partisipasi dan Penguatan Kapasitas Masyarakat. Bandung: Humaniora.

Hubeis, A. V. S. (2011). Pemberdayaan Perempuan dari Masa ke Masa. Bogor: IPB Press.

Huraerah, A. (2008). Pengorganisasian dan Pengembangan Masyarakat: Model dan Strategi Pembangunan Berbasis Kerakyatan. Humaniora.

Iriansyah, H. S. (2017). Tantangan dan Peluang Perempuan dalam Berpolitik di Indonesia. Jurnal Ilmu Pendidikan (JIP) STKIP Kusuma Negara, 8 (2), $1-14$.

Kartasasmita, G. (1996). Pembangunan Untuk Rakyat: Memadukan Pertumbuhan Dan Pemerataan. Jakarta: PT. Pusaka Cisendo.

Nasution, R. (2003). Teknik Sampling. USU Digital Library. Diakses dari http://repository.usu.ac.id/bitstream/ handle/123456789/3755/fkmrozaini.pdf?sequence $=1$

Nasution, S. (2003). Metode Penelitian Kualitatif Naturalistik. Bandung: Penerbit Tarsito.

Poerwadarminta, W. J. S. (2007). Kamus Umum Bahasa Indonesia Edisi Ketiga. Jakarta: Balai Pustaka.

Ramli, S. (2014). Bacaan Wajib Sertifikasi Ahli Pengadaan Barang/Jasa Pemerintah. Jakarta: Visi Media.

Scott, J. (2011). Sosiologi: The Key Concept. Jakarta, Raja Grafindo Persada.

Sugianto. (2017). Urgensi dan Kemandirian Desa dalam Perspektif Undang-
Undang Nomor 6 Tahun 2014. Yogyakarta: CV. Budi Utama.

Suharto, E. (2005). Membangun Masyarakat Memberdayakan Rakyat Kajian Strategis Pembangunan Kesejahteraan Sosial dan Pekerjaan Sosial. PT Refika Aditama.

Suhendra, K., \& Kadmasasmita, A. D. (2006). Peranan Birokrasi dalam Pemberdayaan Masyarakat. Bandung: Alfabeta.

Sumardjono, M. S. W. (1989). Pedoman Pembuatan Usulan Penelitian. Yogyakarta: Fakultas Hukum Universitas Gadjah Mada.

Undang-Undang Nomor 6 Tahun 2014 Tentang Desa

Zubaedi. (2007). Wacana Pembangunan Alternatif: Ragam Prespektif Pembangunan dan Pemberdayaan Masyarakat. Jakarta: Ar Ruzz Media. 